The ranking of economists and management scientists in Europe: a quantitative analysis

Frey, Bruno S ; Eichenberger, Reiner

DOI: https://doi.org/10.1515/jeeh-2000-0408

Posted at the Zurich Open Repository and Archive, University of Zurich ZORA URL: https://doi.org/10.5167/uzh-155089

Journal Article

Published Version

Originally published at:

Frey, Bruno S; Eichenberger, Reiner (2000). The ranking of economists and management scientists in Europe: a quantitative analysis. Journal des économistes et des études humaines, 10(4):575-582.

DOI: https://doi.org/10.1515/jeeh-2000-0408 


\section{THE RANKING OF ECONOMISTS \\ AND MANAGEMENT SCIENTISTS \\ IN EUROPE \\ A quantitative analysis}

Bruno S. Frey* \& Reiner Eichenberger**

\section{Introduction}

Citations gain ever greater importance among scientists, including economists and management scientists. It is relevant both for the career of individual scholars and for comparisons between countries. Citations provide a frequently used measure for capturing the effect of science policy as it focuses on output or performance rather than on input such as expenditures for research. ${ }^{1}$ More fundamentally, a citation count according to countries contributes to answering the question of whether large or small countries are more successful in international scientific competition. As there is no comparable data set, based on citations, available for the management sciences, we use peer nominations as an alternative measure for eminence in this discipline to analyze the same question.

Our analysis allows for the identification of the position of French economists and French management scientists among European ${ }^{2}$ countries. Our

\footnotetext{
* Bruno S. Frey is Professor of Economics at the Institute for Empirical Research in Economics, University of Zurich, Blümlisalpstr. 10, CH-8006 Zurich, Switzerland. Tel: 41-1-6343730; fax: 41-1-6344907. E-mail address: bsfrey@iew.unizh.ch

** Reiner Eichenberger is Associate Professor at the Centre for Public Finance, University of Fribourg, Av. de Beauregard 13, CH-1700 Fribourg, Switzerland. Tel: 41-26-3008265; fax: 41-26-3009678. E-mail address: reiner.eichenberger@unifr.ch

1 The number of publications is another popular measure but it is less able to catch performance than citations are. For recent analyses of economists' publications in refereed journals, see Bommer/Ursprung-1998, Kalaitzidakis/Mamuneas/Stengos-1999 and Kocher/Sutter-2000.

2 According to the Wbo's Who in Economics (first edition Blaug/Sturges-1983, second and third edition Blaug-1986, Blaug-1999) 62.8 percent of the most often cited economists work in the United States. Blaug's data are, however, subject to some omissions and errors (see Frey/Eichenberger-2000).
} 
intention is to provide the statistical facts and to put them into proportion but not to undertake a causal analysis. 3

We consider both the share of leading French scholars in the absolute number of leading scholars in Europe as well as their number corrected for the size of the population. The first section looks at economists, the second at management scientists. The third section draws conclusions.

\section{The Ranking of Economists}

Leading economists are defined as those scholars with the largest number of citations according to the Social Sciences Citation Index (SSCI) over the period 1993-1996. It lists citations from about 200 economics journals, as well as from several hundred journals in the other social sciences. While the SSCI provides a unique data base for analyses of the academic impact of scholars, its shortcomings are well known; ${ }^{4}$ in particular, citations are only attributed to the first author of a publication. It is impossible to count the citations of all living European economists. We therefore restrict our count to a carefully chosen basic set in order not to miss frequently cited economists already at the initial stage. We then selected the most frequently cited ones. Imposing a cut-off of more than 100 citations over the period 1993-96, a set of 160 eminent European economists emerged.

Table 1 exhibits in column (1) the absolute number of leading European economists in the period 1993-96 according to the country they worked in. Column (2) indicates the percentage of the total number and (3) the absolute number weighted by population size.

The table reveals the following main results:

(1) Economists active in the United Kingdom clearly dominate. More than half of all leading European economists ( 57 percent) are located in that country. No other European country has a share of more than 10 percent of all eminent economists.

(2) France with 13 leading economists is ranked second among all European countries. While this position is impressive, the United Kingdom musters seven times as many leading economists as does France.

3 An "Economics of Economics" is slowly emerging, see e.g. Reder-1999, Frey/Eichenberger-1993.

4 See e.g. Quandt-1976, Laband-1985, Frey/Pommerehne-1988, Dusansky/Vernon-1998, Eichenberger/ Arpagaus/Meier-2000. 
(3) The other large European countries (defined as having a population of more than 39 million) are also well placed. Germany is ranked 4 and Italy 5. Only Spain (ranked 9) is trailing behind.

(4) Some small European countries (defined to have a population around 10 million or less) do quite well. Switzerland is ranked 6 , Sweden 8 , and Norway and Denmark 10. Some other small countries, however, are not so successful.

Table 1: Eminent Living European Economists according to Country, Classification based on Citations, 1993-1996

\begin{tabular}{|c|c|c|c|c|c|}
\hline \multirow{2}{*}{ Country } & \multicolumn{2}{|c|}{$\begin{array}{l}\text { unweighted } \\
\text { absolute } \\
\text { number } \\
(\mathrm{N}=160)\end{array}$} & \multirow{2}{*}{$\begin{array}{l}\text { (2) } \\
\text { percentage } \\
\text { of total } \\
\text { number }\end{array}$} & \multicolumn{2}{|c|}{$\begin{array}{l}\text { (3) } \\
\text { weighted }^{\mathbf{a}} \\
\text { by population } \\
\text { (absolute number } \\
\text { per million inhabitants) }\end{array}$} \\
\hline & 91 & (1) & & 1.55 & (1) \\
\hline France & 13 & (2) & 8.13 & 0.22 & (9) \\
\hline Belgium & 10 & (3) & 6.25 & 0.99 & (2) \\
\hline Germany & 9 & (4) & 5.63 & 0.11 & (12) \\
\hline Italy & 8 & (5) & 5.00 & 0.14 & $(10)$ \\
\hline Switzerland & 7 & (6) & 4.38 & 0.99 & (2) \\
\hline Netherlands & 6 & (7) & 3.75 & 0.39 & (6) \\
\hline Sweden & 5 & (8) & 3.13 & 0.57 & (4) \\
\hline Spain & 3 & (9) & 1.88 & 0.08 & $(15)$ \\
\hline Norway & 2 & (10) & 1.25 & 0.46 & (5) \\
\hline Denmark & 2 & (10) & 1.25 & 0.38 & (7) \\
\hline Austria & 1 & (12) & 0.63 & 0.12 & (11) \\
\hline Ireland & 1 & (12) & 0.63 & 0.28 & (8) \\
\hline Hungary & 1 & (12) & 0.63 & 0.10 & (13) \\
\hline Greece & 1 & (12) & 0.63 & 0.10 & (13) \\
\hline
\end{tabular}

numbers in parentheses indicate the ranks

a data for 1995; Source: OECD in Figures, Paris, 1997 
It stands to reason that a large country has more leading economists than a small one. Column four of table 1 therefore exhibits the number of leading economists weighted by the size of the population in the respective country. This normalization dramatically changes the rankings of the various countries:

(1) The United Kingdom, with a population of 59 million and 91 eminent economists, still ranks first (the index of 1.55 is much larger than that of any other European country, the next highest being Belgium and Switzerland, with an index of 0.99).

(2) France drops back sharply; it now only occupies rank 9. The same holds even more strongly for the other three large European countries. Italy is now ranked 10, Germany 12, and Spain 15.

(3) The small countries are well positioned. Belgium and Switzerland now occupy the first two ranks behind the United Kingdom. A majority of the small countries are clear winners. Norway moves up five ranks; Switzerland, Sweden and Ireland improve their position by four ranks. Denmark moves up three ranks, and Austria and Belgium one rank. The Netherlands (with 15 million inhabitants and in the strict sense too large to fit the small countries definition above) also wins one rank. Two of the smaller European countries do not fare so well. Greece and Hungary lose one rank in the population adjusted ranking.

The results are clear: the small countries do much better, while the large countries including France - but with the exception of the United Kingdom - do much worse than they should according to their population endowment.

\section{The Ranking of Management Scientists}

Who constitutes a leading management scholar can be answered by analyzing Cooper's (2000) Who's Who in Management Science. This book is "the first attempt at establishing a Who's Who of leading scholars" (p.vii). It does not claim to be an objective compilation of the most important management scientists. To use citations was explicitly rejected "given the range of subject areas subsumed under management, the multiple authorship problem in such indices and the difficulty of measuring significance of contribution"(p.vii). Of course, these arguments are not necessarily persuasive. However, due to the lack of a data set based on citation counts in the management sciences, for the purpose of this study, Cooper's Who's Who represents the best available alternative measure for eminence in this discipline. Moreover, the author has made a great effort to collect as wide a range of leading management scholars as possible:

"...we wrote to all Fellows of the Academy of Management and the British Academy of Management and asked them to nominate five distinguished management academics who were 
not Fellows of their respective organizations. Then we went to all the major international business scbools and invited all the full Professors to participate. In addition to this, we also invited the Editors, Associate/Consulting Editors and members of the Editorial Boards of many of the leading journals, in the various disciplines that comprise management, to participate" (vii).

The data set contains 337 scholars from 24 countries.

Columns (1) and (2) of table 2 present the ranking of the absolute number, and their share in the total number, of leading management scholars according to countries.

Table 2: Eminent Living European Management Scientists according to Country, Classification based on Citations, 1993-1996

\begin{tabular}{|c|c|c|c|c|c|}
\hline \multirow{2}{*}{$\begin{array}{c}\text { country } \\
\text { United Kingdom }\end{array}$} & \multicolumn{2}{|c|}{$\begin{array}{l}\text { (1) } \\
\text { unweighted } \\
\text { absolute } \\
\text { number } \\
(\mathrm{N}=337)\end{array}$} & \multirow{2}{*}{$\begin{array}{l}\text { (2) } \\
\text { percentage } \\
\text { of total } \\
\text { number }\end{array}$} & \multicolumn{2}{|c|}{$\begin{array}{l}\text { (3) } \\
\text { weighted }^{\mathbf{a}} \\
\text { by population } \\
\text { (absolute number } \\
\text { per million inhabitants) }\end{array}$} \\
\hline & 73 & (1) & & 1.248 & (1) \\
\hline France & 11 & (2) & 9.02 & 0.189 & (8) \\
\hline Netherlands & 8 & (3) & 6.56 & 0.516 & (4) \\
\hline Germany & 6 & (4) & 4.92 & 0.073 & (11) \\
\hline Denmark & 5 & (5) & 4.10 & 0.962 & (2) \\
\hline Switzerland & 4 & (6) & 3.28 & 0.571 & (3) \\
\hline Sweden & 4 & (6) & 3.28 & 0.455 & (5) \\
\hline Italy & 4 & (6) & 3.28 & 0.070 & (12) \\
\hline Spain & 2 & (9) & 1.64 & 0.051 & (13) \\
\hline Norway & 1 & (10) & 0.82 & 0.227 & (6) \\
\hline Finland & 1 & (10) & 0.82 & 0.196 & (7) \\
\hline Austria & 1 & (10) & 0.82 & 0.123 & (9) \\
\hline Hungary & 1 & (10) & 0.82 & 0.098 & (10) \\
\hline Poland & 1 & (10) & 0.82 & 0.026 & (14) \\
\hline
\end{tabular}

numbers in parentheses indicate the ranks

$\mathbf{a}$ data for 1995; Source: OECD in Figures, Paris, 1997 
With respect to the share in the absolute number of leading management scientists, the following observations can be made:

(1) The United Kingdom dominates; it has a far greater number of leading scholars in management science than other countries do.

(2) France has eleven leading management scholars and again occupies the second position. It is better ranked than the other large European countries Germany (ranked 4), Italy (ranked 6, jointly with Sweden and Switzerland), and much better than Spain (ranked 9).

Column (3) of table 2 presents the leading management scholars normalized by population size. As was the case for leading economists, this ranking looks much different:

(1) The United Kingdom is still on top. Its lead over the other European countries is unaffected by taking the size of the underlying population into account.

(2) France drops sharply; it now occupies rank 8. But it is still positioned in front of Germany, Italy and Spain who also all drop back.

(3) The small countries such as Denmark (rank 2), Switzerland (rank 3), Sweden (rank 5), Norway (rank 6) and Finland (rank 7) move up.

\section{Conclusions}

France ranks second in Europe with respect to leading scholars in economics and management science. However, the evidence shows that France does not develop its human resources in the international setting well. France's position in Europe based on the citations of the leading scholars normalized by the size of the population is only rank 9 with respect to economics, and rank 8 with respect to management science. This suggests that there is considerable scope for science policy to improve this situation. 


\section{References}

Blaug, M. (ed.), (1986) Who's Who in Economics? A Biographical Dictionary of Major Economists 1700-1986 ( $2^{\text {nd }}$ edition). Brighton: Wheatsheaf.

Blaug, M. (ed.), (1999) Who's Who in Economics? ( $3^{\text {rd }}$ ed.) Cheltenham: Edward Elgar.

Blaug, M. \& Sturges, P. (eds.), (1983) Who's Who in Economics? A Biographical Dictionary 1700-1981. Brighton: Wheatsheaf.

Bommer, R. \& Ursprung, H.W. (1998) Spieglein, Spieglein an der Wand. Eine publikationsanalytische Erfassung der Forschungsleistungen volkswirtschaftlicher Fachbereiche in Deutschland, Österreich und der Schweiz. Zeitschrift für Wirtschafts- und Sozialwissenschaften, Vol. 118, pp. 1-28.

Cooper, C.L. (2000) Who's Who in Management Science. Cheltenham UK and Brookfield, US: Edward Elgar.

Dusansky, R. \& Vernon, C.J. (1998) Rankings of U.S. Economics Departments. Journal of Economic Perspectives, Vol. 12, $\mathrm{n}^{\circ} 1$ (Winter), pp. 157-170.

Eichenberger, R., Meier, U. \& Arpagaus, R. (2000) Ökonomen, Publikationen und Zitationen: Ein europäischer Vergleich. Perspektiven für Wirtschaftspolitik, Vol. 1, pp. 143-160.

Frey, B.S. \& Eichenberger, R. (1993) American and European Economics and Economists. Journal of Economic Perspectives, Vol. 9, $\mathrm{n}^{\circ} 1$ (Winter), pp. 203-212.

Frey, B.S. \& Eichenberger, R. (2000) Who's Who in Economics? A Note on Mark Blaug's Compendium. Kyklos (forthcoming).

Frey, B.S. \& Pommerehne, w.w. (1988) The American Domination Among Eminent Economists. Scientometrics, Vol. 14, pp. 97-110.

Kalaitzidakis, P., Mamuneas T.P. \& Stengos, T. (1999) European Economics; An Analysis based on publications in the core journals. European Economic Review, Vol. 43, pp. 1150-168.

Kocher, M.G. \& Sutter, M. (2000) The Market for Publications in Top Economics Journals. Economic Journal (forthcoming).

Laband, D.N., (1985) An Evaluation of 50 "Ranked" Economics Departments - By Quantity and Quality of Faculty Publications and Graduate Student Placements and Research Success. Southern Economic Journal, Vol. 52, pp. 216-240.

Quandt, R. (1976) Some Quantitative Aspects of the Economic Journal Literature, Journal of Political Economy, Vol. 84, pp. 741-55.

Reder, M.W. (1999) Economics. The Culture of a Controversial Science. Chicago and London, University of Chicago Press.

Scherer, F. M. (2000) The Emigration of German-Speaking Economists after 1933. Journal of Economic Literature, Vol. 38, pp. 614-626. 
